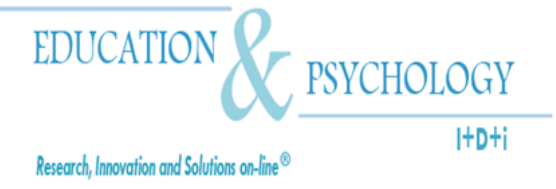

\title{
The Effects of Copy, Cover and Compare with and without Additional Error Drill on Multiplication Fact Fluency and Accuracy
}

\author{
Angela Becker ${ }^{1}$, Thomas McLaughlin ${ }^{1}$, \\ Kimberly P. Weber ${ }^{1}$, Jan Gower ${ }^{2}$ \\ ${ }^{1}$ Department of Special Education, Gonzaga University, Spokane, WA \\ ${ }^{2}$ Spokane Public Schools, Spokane, WA
}

USA

Correspondence: Thomas McLaughlin. Department of Special Education, Gonzaga University, Spokane, WA 99258-0025. USA. E-mail: mclaughlin@gonzaga.edu

(C) Education \& Psychology $\mathrm{I}+\mathrm{D}+\mathrm{i}$ and Editorial EOS (Spain) 


\begin{abstract}
Introduction. The use of copy, cover, and compare has been suggested as an effective classroom intervention procedure. The present case report examined the use of copy cover, and compare with math facts for an elementary student with learning disabilities.

Objectives. The purpose of this research was to increase the correct rate and decrease the error rate for see/write digits in multiplication using copy, cover, and compare. A second objective was to require an additional error correction procedure with copy, cover, and compare and evaluate its effects.
\end{abstract}

Method. Our participant was a fourth-grade student with learning disabilities who had difficulty in math. After baseline, a copy, cover, and compare procedure was implemented. Finally, additional error drill was added to copy, cover, and compare procedure.

Results. The overall outcomes indicated a significant increase in corrects and a decrease in errors with copy, cover and compare. When copy, cover, and compare was combined with error drill, corrects again improved and errors further declined. Fluency also improved with additional error drill.

Discussion. The evidence from the present case report indicates that copy, cover, and compare is an effective procedure. When additional error correction was employed, the efficacy of the procedure improved even further. The benefits, as well as difficulties, for teachers and students using copy, cover, compare with and without and error drill were discussed.

Key Words: Self-Management, Self-Tutoring, Error Correction, Copy, Cover, and Compare; Learning Disabilities

Recibido: 12/03/09 Aceptación inicial: 13/03/09 Aceptación final: 07/05/09 


\section{Efectos del Método Copiar-Tapar-Comparar con y sin correc- ción de errores sobre la fluidez y precisión en las tablas de multiplicar de un estudiante de cuarto curso con dificultades de aprendizaje}

\section{Resumen}

Introducción: La utilización de copiar, tapar y comparar se ha señalado cómo un procedimiento de intervenvión efectivo en el aula. El presente caso examina la utilización de dicha estrategia en relación con hechos matemáticos de un estudiante con dificultades de aprendizaje.

Objetivos: El propósito de esta investigación fue incrementar la eficacia y disminuir la tasa de error en la visión/escritura de dígitos utilizados en la multiplicación utilizando la estrategia de copiar, tapar y comparar. Un segundo objetivo fue utilizar un procedimiento de corrección de los errores utilizando dicha estrategia y evaluar los efectos.

Método: El participante era un estudiante de cuarto curso con dificultades de aprendizaje que había tenido problemas en el área de matemáticas. Tras el establecimiento de la línea base se implementó el procedimiento de pegar, tapar y comparar. Por último, la correción del error fue añadida al procedimiento de copiar, tapar y comparar.

Resultados: Los resultados generales indicaron un aumento de las respuestas correctas y una disminución de los errores mediante el uso del copiar, tapar y comparar. Cuando copiar, tapar y comparar se combinó con la corrección del error, las respuestas correctas aumentaron y los errores disminuyeron. La facilidad también aumentó con la corrección de errores.

Discusión: La evidencia encontrada en el presente informe indica que la eficacia del procedimiento de copiar, tapar y pegar. Cuando se utiliza de forma adicional la corrección de errores, la eficacia del procedimiento se incrementa. Por último, se discuten los beneficios, así como las dificultades, para que profesorado y alumando utilicen la estrategia de copiar, tapar y comparar con y sin corrección de errores.

Key Words: Auto-gestión; Auto-seguimiento; Corrección de errores; Copiar, Tapar y Comparar; Dificultades de aprendizaje.

Received: 03/12/09 Initial Acceptance: 03/13/09 Definitive Acceptance: 05/07/09 


\section{Introduction}

Many children in school today have deficits in mathematics. According to McLeod and Armstrong (1982), teachers report that about $66 \%$ of students with learning disabilities receive remedial math instruction. Research has also shown that most children with learning disabilities can make use of counting strategies to solve basic fact problems, but this often requires large amounts of time to be set aside to complete the work (Connor, 1983; Russell \& Ginsburg, 1984). This slower pace often puts students at a disadvantage and makes them more likely to be behind in mathematics instruction.

The use of teaching procedures and intervention strategies that increase the students' opportunities to interact or respond in the curriculum material, the more likely the student will be to master the information presented and increase his/her fluency and accuracy (Anderson, 1982; Berliner, 1984, 1987; Darch, Carnine, \& Gersten, 1984; Kameenui, 1998; Mourad, 2009; Slavin, 1989). For example, Direct Instruction is an effective teaching strategy that will accomplish this goal. This is because of its emphasis on frequent student-teacher interaction and repeated presentation of academic information (Engelmann \& Carnine, 1982; Kameenui, 1998; McLaughlin, Williams, Howard, \& Reyes, 1995; Stein, Kinder, Silbert, \& Carnine, 2006; Stein, Silbert, \& Carnine, 1981 1994). Using these teaching procedures and curricula leads to increased opportunities to respond and increased immediate corrective feedback from the teacher (Kameenui, 1998). Greenwood (1991) concluded that the amount of time that students actually spend engaged or working in academic instruction is the best single predictor of achievement for students with learning problems.

An academic intervention that also provides numerous opportunities for responding and immediate feedback is the cover, copy, and compare procedure (Skinner, Beatty, Turco, \& Rasavage, 1989; Skinner, McLaughlin, \& Logan, 1997). The efficacy for spelling has been impressive (Haring, Lovitt, Eaton, \& Hanson, 1978; Hubbert, Weber, \& McLaughlin, 2000; McAuley \& McLaughlin, 1992; Murphy, Hern, Williams, \& McLaughlin, 1990), and mathematics (Skinner, Bamberg, Smith, \& Powell, 1993; Skinner et al., 1989; Stading, Williams, \& McLaughlin, 1995). Copy, cover, and compare requires the student look at the fact, write the fact while saying each part aloud or silently, cover the fact, write it again from memory, and finally compare the written fact to see if it was written correctly. If the math fact was incor- 
rect, an error correction procedure and error drill is typically implemented (McLaughlin \& Skinner, 1996; Skinner et al., 1997).

\section{The Present Study}

The purpose of this study was to evaluate the effectiveness of the copy, cover, and compare method without and with additional error drill on mathematics skills for see-to-write digits in multiplication. In addition, we wanted to combine copy, cover, and compare with a precision teaching methodology (Lindsley, 1991) as we had done previously (Noland, McLaughlin, \& Sweeney, 1994), but this time in math and with a younger student. Finally, we sought to improve the subject's fluency (Binder, 1994; Miller \& Heward, 1992) in writing multiplication facts.

\section{Method}

\section{Participant}

The participant in the study was a 10-year-old female elementary student. The participant was assigned to the regular fourth grade classroom, but received special education services in the areas of math and reading. Based on her scores from the Woodcock Johnson Psycho-educational Battery (Woodcock \& Johnson, 1977), she was over 1.0 years below grade level in both reading and math. Also, according to teacher reports, she was having difficulty with her basic facts in multiplication.

The study took place in the participant's resource room located in an elementary school in the Pacific Northwest. During all sessions, the first author, classroom teacher, instructional assistant, and approximately 5-6 other students were present in the room. Data were collected each afternoon. During the 30-minute math session each morning, the student would work on her daily math lesson from her textbook and then spend the last 10 minutes practicing the math facts. Then the student was timed for one minute on the multiplication facts at the end of each math class. 


\section{Instruments}

A sheet of 90 to 100 math problems (probe sheet) was employed. After baseline when cover, copy, and compare was in effect, a cover, copy, and compare sheet (McLaughlin \& Skinner, 1995; Stading et al., 1996) was employed. These probe sheets (Lindsley, 1991) were developed by the first author and represented the type of problems that were taught. The category and type of math facts the student had difficulty varied every four lessons (i. e. multiply by 2's, by 3's, by 4's, etc.). These sheets contain four columns. The first rcolumn presents the problem and solution. The second column allows the student to copy the problem and solution. The third column provides the space for the student to copy the problem and its product from memory. The last column provides a place so the student can copy the problem and its solution three times if an error occurred. The dependent variable was the number of corrects and errors per minute in see to write multiplication facts from a probe sheet (Lindsley, 1991). The student's math sheet was scored by the first author. The behavior measured was the number of correct problems or in error written on the math sheet by the participant. Errors were scored if the student's quotients were incorrectly written, illegible, or omitted. Also any problem that was not completed, the answer was also tallied as error. After each math sheet was completed, the student would briefly review any errors with the first author and plan what math materials she needed to complete the next class day.

\section{Procedure and Data Analysis}

An ABC single case design (Barlow, Nock, \& Hersen, 2008; Kazdin, 1982) was used to evaluate the effects of the two interventions on the rate of see-to-write multiplication facts with our participant. We also carried out a non parametric analysis of variance procedure for both corrects and errors across each condition. Follow up tests between the various phases were also completed. Descriptions of the various experimental manipulations follow.

Baseline. Baseline lasted for three class sessions and consisted of a one-minute timed probe sheet that contained 90 of the 100 basic multiplication facts. Problems with zero as a factor were excluded because the student exhibited 100\% proficiency on probe sheets which contained only problems with zeroes as the second factor on four of four consecutive trials. The first author recorded the number of corrects and errors made by the student during the one-minute timed probe. 
Copy, cover, and compare. Each session, the student was given a copy, cover, and compare sheet, which contained 10 multiplication facts and was allowed to complete the sheet. After completing the copy, cover, and compare sheet (McLaughlin \& Skinner, 1995; Stading et al., 1996), the student was given a probe sheet of 90 problems and timed for one minute by the first author. The first author recorded the corrects and errors made by the student during the timing. After each probe sheet was completed, the student would briefly review any errors with the first author and plan what she math materials she needed to complete in the next class day. The child also received praise for increased performance and for working hard. This condition was in effect for seven school days.

Copy, cover and compare plus error drill. During this phase, extra error drill was added to the copy, cover, and compare sheets. The student completed the sheets, then worked the timed math sheet, with corrects and errors recorded by the author. After the student completed the probe sheet, the author would review the errors made by the participant. Error drill was then implemented. This consisted of the author correctly modeling the incorrect math facts written by the student. The student repeated the entire fact out loud several times and wrote it down on another sheet of paper. After error drill was completed, the participant would repeat out loud all missed facts written on the paper. This condition was in effect for 10 data days and two weeks of school. It ended with the conclusion of the student teaching practicum required for graduation and an endorsement in special education in the P-12 setting (McLaughlin, Williams, Williams, Peck, Derby, Bjordahl, \& Weber, 1998).

\section{Results}

\section{Reliability of Measurement}

Reliability of measurement was taken for each of the probe sheets. The first author and a teaching assistant in the room graded each of sheets. The grading of each person was compared. If both graded the problem in the same manner it was scored as an agreement, any differences in grading were scored as disagreements. Reliability of measurement was calculated by dividing the number of agreements by agreements plus disagreements and multiplying by 100. Reliability of measurement for both corrects and errors was $100 \%$. 
The overall results showed an increase in correct responses and a gradual decrease in errors for the participant. During baseline, the participant's correct rate was 34.0 digits with an average error rate of 56. 0. During the copy, cover and compare phase, the number of correct digits ranged from 23 to 90 , with a mean of 54. 5. The number of errors also decreased during this condition $(M=35.571$; range 0 to 67$)$. During the copy, cover, and compare plus error drill phase, the number of corrects further increased $(M=83.4$; range 70 to 90$)$. The number of errors during this condition declined as well. Errors ranged from 0 to 20, with an overall mean of 6.6.

A repeated measures analysis of variance for both corrects and errors was carried out. There was a significant difference by treatments for both corrects $(F=17.951, d f=2, p=.01)$ and errors $(F=17.951, d f=2, p=.01)$. Follow up Sheffe F-tests found a significant difference between baseline and copy, cover, and compare plus error drill $(F=14.611 ; p=.05)$, and between copy, cover, and compare with and without error drill $(F=12.208 ; p=.05)$. Follow up Sheffe F-tests were also significant between baseline and copy, cover, and compare plus error drill $(F=14.611 ; p=.05)$, and between copy, cover, and compare with and without error drill $(F=12.208 ; p=.05)$ for errors.

\section{Discussion}

The results of this study indicate the effectiveness of the copy, cover, and compare self-managed drill and practice procedure. The copy, cover, and compare procedure improved correct rate and decreased errors. These findings replicate the work of Skinner and his colleagues (Skinner et al., 1989, 1994), and our work in math facts (Bolich, Kavon, McLaughlin, Williams, \& Urlacher, 1995, Ozaki, Williams, \& McLaughlin, 1996; Stading et al., 1995). Copy cover, and compare was made even more effective with it was combined with error drill for see-to-write multiplication facts. These findings support our work with extra error drill in reading (Abrams \& McLaughlin, 1995; Gregori \& McLaughlin, 1995). The present outcomes add to the growing literature regarding the efficacy of error correction (Kameenui, 1998; Stein et al., 1981, 1997).

As the results revealed, the student's corrects increased enough to meet the standard of 70 to 90 digits per minute for see-to-write math facts, but it required time more to decrease 
the errors than to increase the corrects. This may have been due to the fact that each probe was timed; therefore, many errors may have been a result of a lack of fluency rather than a lack of knowledge on the student's part. However, the noticeable decrease in errors after error drill was implemented can be viewed as indicative of an increase in fluency, especially because the number of corrects continued to meet the criterion standard.

Daily data collection and analysis have been cited as a strength of precision teaching (Auerbach, 1985; Binder, 1994; Lindsley, 1991; West, Young, \& Spooner, 1990). The child appeared to enjoy the daily routine of precision teaching when it was combined with copy, cover, and compare. An interesting sidelight of present study was the student's perfect attendance throughout the data collection days. The student never missed a day of school. Prior to the systematic data collection and analysis found in precision teaching, the child had been absent a great deal with few days of consecutive school attendance.

It also appeared that consistent assessment and daily drill and practice helped with the child's acquisition of new skills with math facts. This is especially important for students who are performing below grade level in one or more subject areas. Related routines have been suggested a very important way to assist children have academic problems at school (Belfiore $\&$ Hutchinson, 1998). These routines can be established via scheduling and increasing the number of minutes devoted to academic instruction (Belfiore \& Hutchinson, 1998), setting up classroom structure (Ayllon, Layman, \& Burke, 1972), having a classroom token economy in place (McLaughlin \& Williams, 1988), or by employing various opportunity to respond procedures such as classwide peer tutoring (Greenwood, Delquadri, \& Hall, 1991), copy, cover, and compare (Skinner et al., 1997) or Direct Instruction curricula and teaching procedures (Kameenui, 1998; Stein et al., 1997).

Another intervention which might be introduced either independently or in conjunction with the copy, cover and compare and error drill could be the use of the Direct Instruction flash cards procedure (Brasch, Williams, \& McLaughlin, 2008; Silbert et al., 1994; Stein et al., 2006; Stone, McLaughlin, \& Weber, 2002). Also, SAFMEDS (McDade, Austin, \& Olander, 1985) could be employed with copy, cover, and compare procedures. This would involve a bit more preparation of materials, but most likely would serve to produce similar results or even enhance those already achieved. 
There are limitations in the case report. First, since only an $\mathrm{ABC}$ single case replication design was employed, other factors (e.g. history, maturation, etc) could have been responsible for the participant's changes in performance. By using an alternating treatments design (Barlow et al., 2008; Kazdin, 1982) or by counterbalancing the introduction and length of treatments (Malone \& McLaughlin, 1997), such threats to internal validity could be ruled out. Also, the duration of data collection was brief. However, data collection ceased due to the completion of student teaching by the first author as well as the meeting of the performance standard in math. Additional research could examine the use of the two procedures for greater periods of time and with more students.

Overall, the intervention was viewed as successful by the author and the participant. The copy, cover, and compare sheets and error drill took minimal amounts of time (10 to 15 minutes), which is a small investment on both the teacher's and the student's part. In addition, the student enjoyed being timed during her probe sheets, and took great pride in completing the maximum number of problems in the allotted time.

\section{Acknowledgment}

This research was completed in partial fulfillment of an Endorsement by the first author in Special Education from Gonzaga University and the State of Washington. Special requests for reprints should be addressed to the authors, Department of Special Education Gonzaga University, Spokane, WA 99258-0025 or via email at mclauglin@gonzaga.edu 


\section{References}

Anderson, J. R. (1982). Acquisition of cognitive skill. Psychology Review, 89, 369-406.

Auerbach, S. (Ed.) (1985). Special edition: Precision Teaching. B.C. Journal of Special Education, 9, [Whole Issue].

Ayllon, T. A., Layman, D., \& Burke, S. (1972). Disruptive behavior and reinforcement of academic performance. The Psychological Record, 22, 315-323.

Barlow, D. H., Nock, M., Hersen, M. (2008). Single case research designs: Strategies for studying behavior change ( $3^{\text {rd }}$ ed.). New York: Allyn and Bacon.

Belfiore, P. J., \& Hutchinson, J. M. (1998). Enhancing academic achievement through related routines: A functional approach. In T. S. Watson \& F. M. Graham (Eds.), Handbook of child behavior therapy (pp. 83-97). New York: Plenum.

Berliner, D. C. (1984). The half-full glass: A review of research on teaching. In P. L. Hosford (Ed.), Using what we know about teaching (pp. 51-85). Alexandria, VA: Association for Curriculum and Development.

Berliner, D. C. (1987, August). New knowledge for new roles: Research on teaching. Paper presented at the meetings of the American Psychological Association, New York City.

Binder, C. (1994). Measurably superior instructional methods: Do we need sales and marketing? In R. Gardner III, D. M. Sainato, J. O. Cooper, T. E. Heron, W. L. Heward, J. W. Eshelman, \& T. A. Grassi (Eds.), Behavior analysis in education: Focus on measurably superior instruction (pp. 21-41). Pacific Grove, CA: Brooks/Cole.

Bolich, B., Kavon, N., McLaughlin, T. F., Williams, R. L., \& Urlacher, S. (1995). Effects of a copy cover compare procedure and a token economy on the retention of basic multiplication facts by two middle school students with ADD/ADHD. B. C. Journal of Special Education, 19, 1-10.

Brasch, T. L., Williams, R. L., \& McLaughlin, T. F. (2008). The effects of a direct instruction flashcard system on multiplication fact mastery by two high school students with ADHD and ODD . Child \& Family Behavior Therapy, 30(1), 51-59..

Connor, F. P. (1983). Improving school instruction for learning disabled children: The Teachers College Institute. Exceptional Education Quarterly, 4, 23-44.

Darch, C., Carnine, D., \& Gersten, R. (1984). Explicit instruction in mathematical problem solving. Journal of Educational Research, 4, 155-165.

Engelmann, S., Becker, W. C., Carnine, D., \& Gersten, R. (1988). The Direct Instruction Follow Through Model: Design and outcomes. Education and Treatment of Children, 11, 303-317. 
Engelmann, S., \& Carnine, D. (1982). Theory of instruction. New York: Irvington.

Greenwood, C. R. (1990). The longitudinal analysis of time to learn, engagement, and academic achievement in urban vs. suburban schools. Exceptional Children, 57, 521-535.

Greenwood, C. R., Delquadri, J., \& Hall, R. V. (1991). Longitudinal effects of classwide peer tutoring. Journal of Educational Psychology, 81, 371-383.

Gregori, A., \& McLaughlin, T. F. (1996). Effects of error drill and assisted reading on oral reading. Journal of Precision Teaching and Celeration, 13(2), 23-27.

Haring, N. G., Lovitt, T. C., Eaton, M. D., \& Hanson, C. L. (Eds) (1978). The fourth r: Research in the classroom. Columbus, $\mathrm{OH}$ : Merrill.

Hubbert, E. R., Weber, K. P., \& McLaughlin, T. F. (2000). A comparison of copy, cover, and compare, and a traditional spelling intervention for an adolescent with a conduct disorder. Child \& Family Behavior Therapy, 22(3), 55-68.

Kameenui, E. J. (1998). The rhetoric of all, the reality of some, and the unmistakable smell of mortality. In J. Osborn \& F. Lehr (Eds.), Literacy for all (pp. 319-338). New York: Guilford.

Kazdin, A. E. (1982). Single case research design: Methods for clinical and applied settings. New York: Oxford.

Lindsley, O. R. (1991). Precision teaching's unique legacy from B. F. Skinner. Journal of Behavioral Education, 1, 253-266.

Malone, R., \& McLaughlin, T. F. (1997). The effects of reciprocal peer tutoring with a group contingency on quiz performance in vocabulary with seventh and eighth grade students. Behavioral Interventions, 12, 27-40.

McAuley, S. M., \& McLaughlin, T. F. (1992). Comparison of add-a-word and compu spell programs with low achieving students. Journal of Educational Research, 85, 362-369.

McDade, C. E., Austin, D. M., \& Olander, C. P. (1985). Technological advances in precision teaching: A comparison between computer testing and SAFMEDS. Journal of Precision Teaching, 4, 49-53.

McLaughlin, T. F. Williams, B. F., Howard, V. F., \& Reyes, R. (1995). Data-based and effective classroom procedures to assist Native American children with fetal alcohol syndrome and fetal alcohol effects. Corrective and Social Psychiatry, 41(3), 42-51.

McLaughlin, T. F., \& Stone, S. (2000, May). The effects of copy, cover, and compare and flash cards on mastering basic division facts with a fourth grade student. Poster presented at the Association for Behavior Analysis Convention: An International Organization, Washington DC. 
McLaughlin, T. F., Williams, B. F., Williams, R. L., Peck, S. M., Derby, K. M., Bjordahl, J. M., \& Weber, K. M. (1999). Behavioral training for teachers in special education: The Gonzaga University program. Behavioral Interventions, 14, 83-134.

McLaughlin, T. F., \& Williams, R. L. (1988). The token economy in the classroom. In J. C. Witt, S. N. Elliott, \& F. M. Gresham (Eds.). Handbook of behavior therapy in education (pp. 469-487). New York: Plenum.

McLeod, T., \& Armstrong, S. (1982). Learning disabilities in mathematics-skill deficits and remedial approaches at the intermediate and secondary grades. Learning Disability Quarterly, 5, 305-311.

Miller, A. D., \& Heward, W. L. (1992). Do your students really know their math facts? Using daily time trials to build fluency. Intervention in School and Clinic, 28(2), 98-104.

Mourad, A. (2009). The effectiveness of a program based on self-regulated strategy development on the writing skills of writing-disabled secondary school students. Electronic Journal of Research in Educational Psychology, 17, 7(1), 5-24.

Murphy, J. F., Hern, C. L., Williams, R. L., \& McLaughlin, T. F. (1990). The effects of the copy, cover, and compare approach in increasing spelling accuracy with learning disabled students. Contemporary Educational Psychology, 15, 378-386.

Noland, E., McLaughlin, T. F., \& Sweeney, W. J. (1994). The effects of precision teaching and add-a-word spelling on spelling performance of an adult graduate student. Journal of Precision Teaching, 11(2), 14-18.

Ozaki, C., Williams, R. L., \& McLaughlin, T. F. (1996). Effects of copy/cover/compare drill and practice procedures for multiplication facts mastery with a sixth grade student with learning disabilities. B. C. Journal of Special Education, 20(2), 67-76.

Russell, R. L., \& Ginsburg, H. P. (1984). Cognitive analysis of children's mathematics difficulties. Cognition and Instruction, 1, 217-244.

Sante-Delli. A., McLaughlin T. F., \& Weber, K. P. (2001). The use and evaluation of a Direct Instruction flash card strategy on multiplication facts mastery with two students with ADHD. Journal of Precision Teaching and Celeration, 17(2), 68-75.

Silbert, J., Carnine, D. W., \& Stein, M. (1981). Direct instruction mathematics. Columbus, $\mathrm{OH}$ : Charles E. Merrill.

Silbert, J., Carnine, D., \& Stein, M. (1994). Direct instruction mathematics. Upper Saddleback, NJ: Prentice-Hall/Merrill. 
Stein, A., Kinder, D., Silbert, J., \& Carnine, D. W. (2006). Designing effective mathematics instruction: A direct instruction approach. Upper Saddle River, NJ: Merrill/Pearson Education, Inc.

Skinner, C. H., Bamberg, H,. W., Smith, E. S., \& Powell, S. S. (1993). Cognitive, cover, copy, and compare: Subvocal responding to increase rates of accuracy division responding. Remedial \& Special Education, 14(1), 49-56,

Skinner, C. H., Beatty, K. L., Turco, T. L., \& Rasavage, C. (1989). Cover, copy, \& compare: A method for increasing multiplication performance. School Psychology Review, 18, 412-420.

Skinner, C. H., McLaughlin, T. F., \& Logan, P. (1997). Cover, copy, and compare: A selfmanaged academic intervention across skills, students, and settings. Journal of Behavioral Education, 7, 295-306.

Slavin, R. E. (1989). Students at risk for school failure: The problem and its dimensions. In R. E. Slavin, N. L. Karweit, \& N. A. Madden (Eds.), Effective programs for students at risk (pp. 3-19). Needham Heights, MA: Allyn \& Bacon.

Stading, M., Williams, R. L., \& McLaughlin, T. F. (1996). Effects of a copy, cover, and compare procedure on multiplication facts mastery with a third grade girl with learning disabilities in a home setting. Education and Treatment of Children, 19, 425-434.

Stein, M., Silbert, J., Carnine, D. (1997). Designing effective mathematics instruction: A direct instruction approach. Upper Saddle River, NJ: Merrill/Prentice Hall.

Stone, S., McLaughlin, T. F., \& Weber, K. P. (2002). The use and evaluation of copy, cover, and compare with rewards and a flash cards procedure with rewards on division math facts mastery with a fourth grade girl in a home setting. International Journal of Special Education, 17(2), 82-91.

West, R. P., Young, K. R., \& Spooner, F. (1990). Precision teaching: An introduction. Teaching Exceptional Children, 22(3), 4-8.

Woodcock, R. W., \& Johnson, M. B. (1977). Woodcock-Johnson Psycho-Educational Battery. Allen, TX: DLM Teaching Resources. 